\title{
A Case of Multiple Myeloma in Bilateral Paranasal Sinuses with Loss of Vision
}

\author{
Woo Sung Park, Yong Hee Cho, Byung Ki Yoon, and Jin Hyeok Jeong \\ Department of Otolaryngology-Head and Neck Surgery, College of Medicine, Hanyang University, Seoul, Korea \\ 시력소실을 주소로 내원한 양측성 부비동 다발성 골수종 1 예 \\ 박우성 · 조용희 · 윤병기 · 정진혁 \\ 한양대학교 의과대학 이비인후-두경부외과학교실
}

\author{
Received July 1,2015 \\ Revised August 9, 2015 \\ Accepted August 24, 2015 \\ Address for correspondence \\ Jin Hyeok Jeong, MD \\ Department of Otolaryngology- \\ Head and Neck Surgery, \\ College of Medicine, \\ Hanyang University, \\ 222-1 Wangsimni-ro, Seongdong-gu, \\ Seoul 04763, Korea \\ Tel $+82-31-560-2368$ \\ Fax $+82-31-566-4884$ \\ E-mail ent@hanyang.ac.kr
}

Plasmacytoma refers to malignant plasma cell tumor, which consists of abnormal proliferation of plasma cells. It can be classified into several types, multiple myeloma, solitary medullary plasmacytoma and extramedullary plasmacytoma according to clinical and histological aspects of the tumor. Multiple myeloma is the most common plasmacytoma and its main feature is the infiltration of plasma cells into the bone marrow. Over $10 \%$ of plasma cell count among the nuclear cells in the bone marrow biopsy allows diagnosis of multiple myeloma. This involves multiple organs and extramedullary sites including the spleen, liver, lymph nodes and kidney; however, the involvement of nasal cavity and paranasal sinus is rare. Recently, we experienced a case of multiple myeloma, which was present in both nasal cavities and paranasal sinuses. The case was treated with chemotherapy and radiotherapy followed by autologous bone marrow transplantation. We report on it with literature review.

Korean J Otorhinolaryngol-Head Neck Surg 2016;59(4):317-22

Key Words Multiple myeloma $\cdot$ Nasal cavity $\cdot$ Paranasal sinus $\cdot$ Plasma cell $\cdot$ Plasmacytoma.

\section{서 론}

형질세포종(plasmacytoma)은 형질세포(plasma cell)의 단 일 클론 증식을 특징으로 갖는 드문 종양의 일종이다. 임상 양상 및 형태학적 특성에 따라 다발성 골수종(multiple myeloma), 고립 골수종(solitary medullary plasmacytoma) 및 골수 외 형질세포종(extramedullary plasmacytoma)으로 분류할 수 있으며, ${ }^{1)}$ 개개의 형질세포종이 서로 연관관계를 가 지고 상호 변화 또는 발전할 수 있는 연속적인 질환으로 생각 되고 있다. 골수 외 형질세포종의 경우 두경부 영역에서 약 $90 \%$ 정도 발생하며2) 특히 비인강 및 부비동을 포함한 상기 도와 소화관에 주로 발생한다. ${ }^{3)}$ 다발성 골수종은 형질세포 질환 중 가장 대표적이며 흔한 질환으로 종양성의 형질세포 에 의한 골수 침범 및 혈중 칼슘 증가, 신장 기능 저하, 빈혈 등 의 특징을 가진다. 골수 외 형질세포종과 달리 부비동에서 발
견되는 경우는 매우 드문 것으로 알려져 있으며) 특히 양측 부비동 또는 비강에 침범하는 경우는 더욱 드문 것으로 알려 져 있다. ${ }^{5)}$

저자들은 좌측 시력 저하를 주소로 내원한 환자에서 좌측 접형동 내 종괴 소견을 발견하고, 조직검사 및 수술 도중 반 대측 비강과 부비동의 이상소견을 추가적으로 발견하여, 최종 적으로 양측 부비동 및 비강을 침범한 다발성 골수종으로 진 단된 예를 경험하였기에 문헌 고찰과 함께 보고하는 바이다.

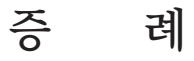

58세 남자 환자가 좌측 시력 저하를 주소로 내원하였다. 증 상은 내원 2개월 전부터 시작되었으며, 2주 전부터 악화되어 개인 안과에 들러 본원 신경과로 의뢰되었고, 신경과에서 뇌 자기공명영상 후 접협동 종양에 의한 시력 저하로 진단되어 
이비인후과로 협진 의뢰되었다. 과거력 및 가족력상 특이사 항은 없었으며, 안과 검사상 우측 시력 1.0 , 좌측 시력 0.5 로 확인되었으며, 정상적인 외안근 움직임 소견을 보였고, 시야
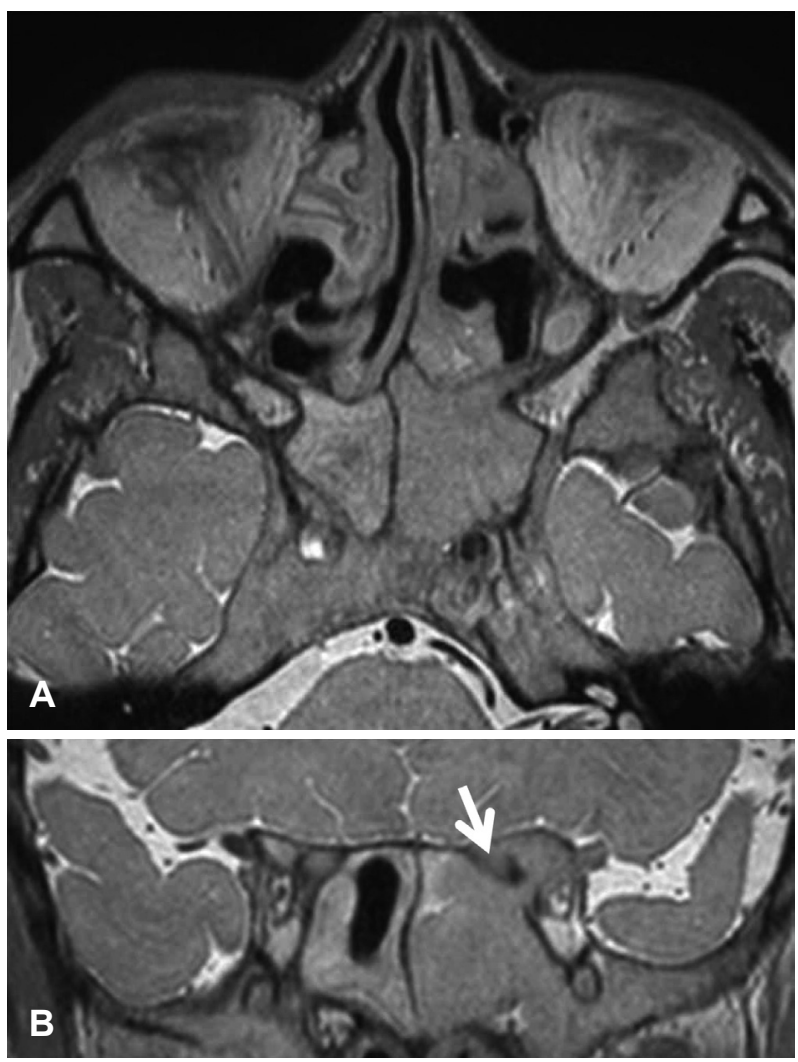

Fig. 1. Preoperative MRI scans showing left sphenoid mass with iso-to-hypo signal intensitiy in T2 WI (A). It was encircling left optic canal (arrow) (B).
검사에서도 이상소견은 관찰되지 않았다. 혈액검사 및 소변 검사에서는 특이소견은 보이지 않았고, 특히 헤모글로빈 $13.8 \mathrm{~g} / \mathrm{dL}$, 혈장칼슘 농도 $8.8 \mathrm{mg} / \mathrm{dL}$ 로 정상 범위였다. 시행 한 뇌 자기공명영상검사상 $\mathrm{T} 2$ 강조영상에서 저신호강도를 보 이는 종괴가 좌측 접형동에서 관찰되었으며, 이는 좌측 시신 경관을 감싸고 주변 조직으로 침윤하는 양상을 보였고, 양측 범부비동염이 동반되어 있었다(Fig. 1). 환자는 비폐색, 농성 비루, 후비루 등 부비동염 증상이 있었고 비내시경 검사에서 좌측으로 만곡된 비중격과 양측 비강 내 폴립 및 농성 비루 가 관찰되었다(Fig. 2). 조영 증강 부비동 전산화단층촬영에 서 좌측 접형동 종괴 이외에 양측 전두동, 상악동, 사골동 및 우측 접형동의 부비동염 소견을 확인할 수 있었다(Fig. 3). 좌 측 접형동 종괴에 대해 림프종 등의 악성 종양 가능성을 의 심하여 조직검사를 계획하였고, 추후 항암치료 등으로 인한 면역저하 상태를 염두에 두고 양측 부비동염에 대한 부비동 내시경 수술도 함께 계획하였다. 전신마취 하에 수술을 진행 하였다. 비중격 교정술을 먼저 시행하여 접근 경로를 확보하 고, 일반적인 부비동 내시경 수술 과정에 따라 좌측부터 수 술이 진행되었다. 사골동 절제술 후 좌측 접형동 내에서 쉽 게 출혈되며, 표면이 평활한 양상의 종괴가 돌출되어 있었고, 일부를 떼어내어 동결절편 조직검사를 시행하였다. 좌측 전 두동, 상악동 수술 후 우측 부비동염에 대한 수술을 같은 순 서대로 진행하였으며, 술 중 양측 중비갑개 및 상비갑개를 포 함한 부비동 점막에서도 출혈이 많고, 혈관 수축제에 잘 수 축되지 않는 일반적인 부비동염의 점막과 다른 이상 점막소 견이 관찰되어 이 부위들에서 추가로 조직검사를 시행하였
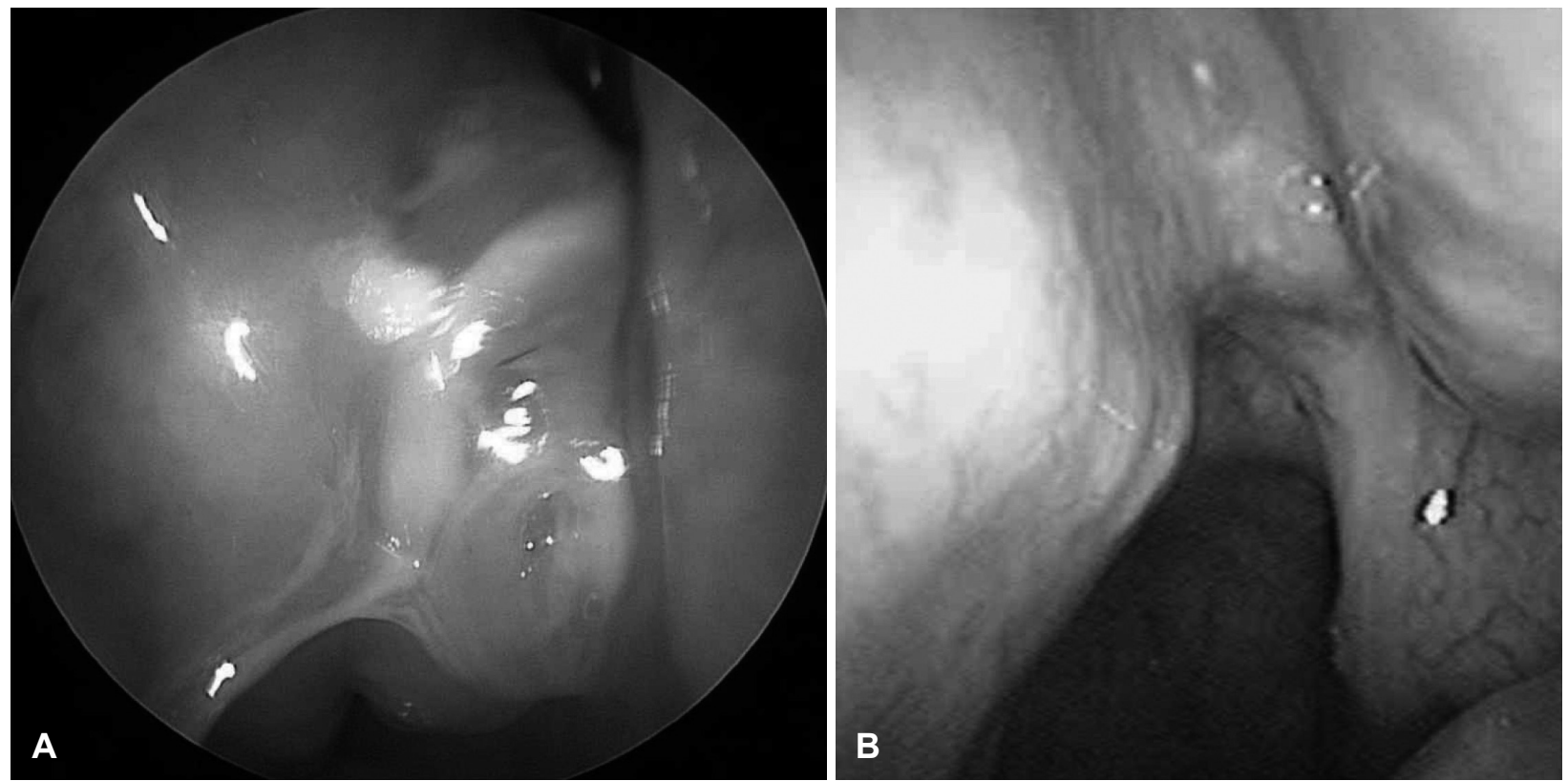

Fig. 2. Nasal endoscopic view showing right nasal polyp (A) and left posterior nasal drip (B). 


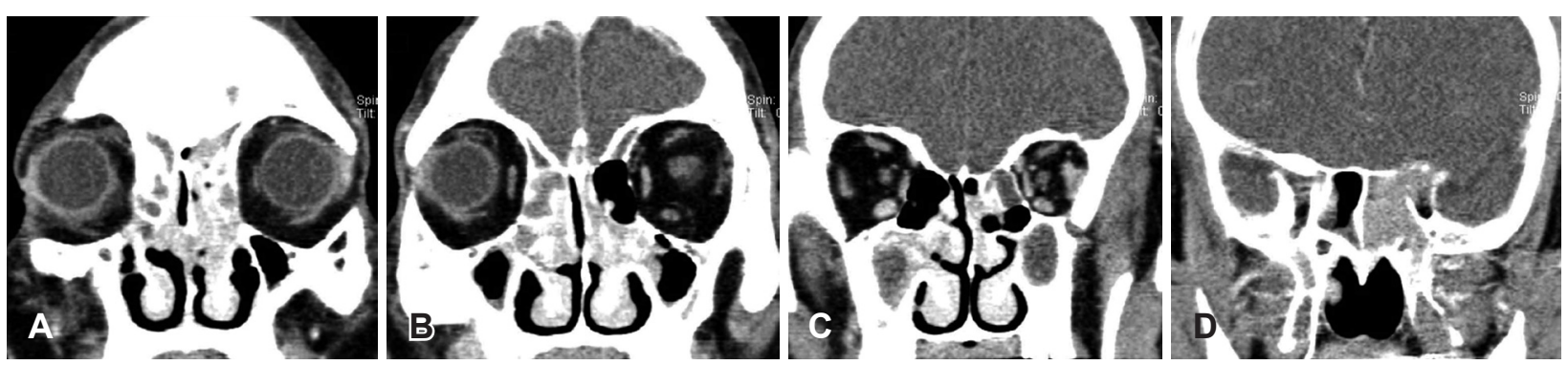

Fig. 3. Preoperative CT with contrast enhance scan showing both frontal sinusitis (A), ethmoid sinusitis (B), maxillary sinusitis (C), right sphenoid sinusitis and left sphenoid mass (D).
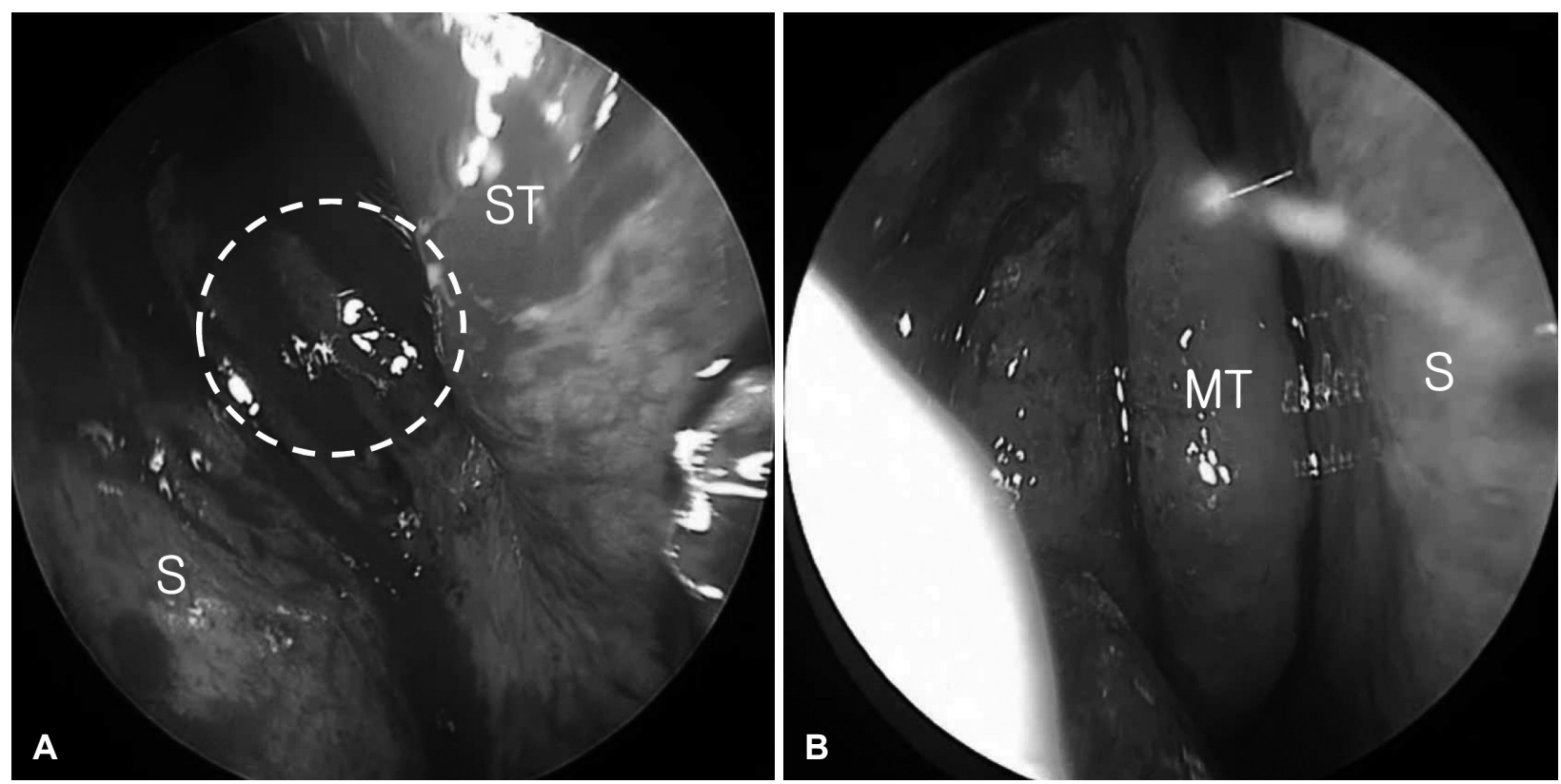

Fig. 4. Intraoperative endoscopic views. Smooth easily bleeding fragile mass was note around left sphenoid sinus ostium (A, dot circle). Easily bleeding and non-shrink mucosa was noted around right MT and middle meatus (B). All of them were revealed as plasmacytoma. S: nasal septum, ST: superior turbinate, MT: middle turbinate.

다(Fig. 4). 좌측 접형동에서 채취한 조직에 대한 동결절편 검사는 형질세포종으로 진단되었으며, 접형동 내 종양에서 출혈이 많고 종양이 시신경을 둘러싸고 있어 완전제거가 불 가능할 것으로 판단되어 향후 골수 검사 등을 시행한 후 방 사선 및 항암치료를 계획하고, 완전 절제는 시도하지 않고 패 킹 후에 수술을 종료하였다. 최종 병리 조직 검사상 좌측 접 형동뿐만 아니라 추가로 시행한 양측 중비갑개 및 상비갑개 주위 점막 조직에서도 형질세포종이 확인되었다. 수술 다음 날 비강 내 패킹을 제거하였고, 골수 침범 여부 확인을 위해 골수 천자 검사를 시행하였다. 미분화 형질세포 $31.8 \%$ 가 나와 다발성 골수종으로 진단되었으며, 병리 조직 소견상 CD38 면 역염색 및 lambda light chain 면역염색에 양성 소견을 보여 free lambda type의 다발성 골수종의 소견에 합당하였다 (Fig. 5). 추가적인 검사 및 치료 위해 혈액종양내과로 전과되 었다. 수술 후 7일째 전신전이 확인을 위해 양전자 단층촬영
을 시행하였으며, 다발성 골전이 및 림프절 전이를 확인할 수 있었다(Fig. 6). 이후 환자는 타원에서의 치료를 원하여 타원 입원 후 두개저 및 좌측 안와에 10 회에 걸쳐 $2500 \mathrm{cGy}$ 의 방 사선 치료를 시행하였고, thalidomide 및 cyclophosphamide, bortezomib으로 항암화학치료를 시행하였다. 시력에는 별다 른 호전 또는 악화 없는 상태로, 술 후 10 개월째인 현재까지 특별한 합병증 없이 추적 관찰 중이다.

\section{고 찰}

형질세포의 비정상적 증식을 특징으로 하는 형질세포종 은, 1846년 Dalrympic과 Bence-Jone's에 의해 보고된 이후, Willis $^{1}$ 에 의해 임상양상 및 병리학적 양상에 따라 다발성 골 수종(multiple myeloma), 고립 골수종(solitary medullary plasmacytoma) 및 골수 외 형질세포종(extramedullary plas- 


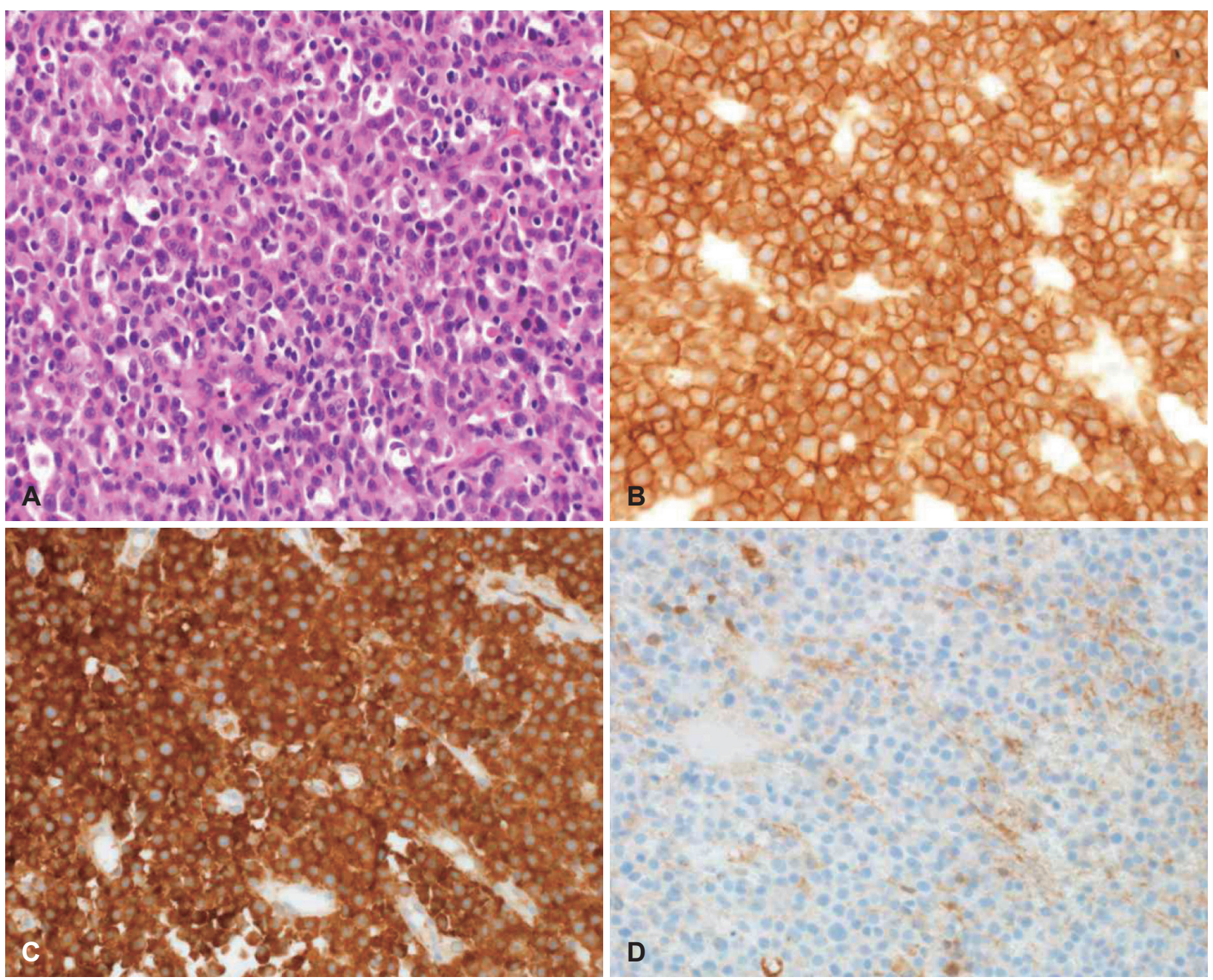

Fig. 5. Pathologic findings. Atypical plasma cells with abundant cytoplasm and hyperchromatic nuclei were shown $(H \& E, \times 400)(A)$. Immunohistochemical staining shows positive on CD38 $(\times 400)(B)$, and lambda light chain $(\times 400)(C)$. Kappa light chain staining was negative $(\times 400)(D)$.

Fig. 6. PET CT. Heterogeneously increased fluodeoxyglucose uptake was noted in sphenoid bone (A) and multiple bones with multiple lymph nodes uptake (B).

macytoma)으로 분류되었다. 이 중 가장 흔하게 보고되고 있 는 다발성 골수종은 ${ }^{6}$ 혈청과 소변 중에 증가하는 비정상 단백 소견(Bence-Jones protein, monoclonal gammopathy)을 특 징으로 하며, 40세 이전에는 매우 드물게 발생하지만, 그 이 후 연령 증가에 따라 발생률이 상승하여 진단 시 평균 연령은 62세로 보고되고 있다. ${ }^{78)}$ 미국과 유럽의 발생률은 인구 10 만 명당 3 4명으로 보고되어 있으며 ${ }^{7)}$ 국내의 경우에도 인구 10 만 명당 3.8명으로 보고되어 있다. ${ }^{9)}$ 다발성 골수종의 진단기준 으로는 미국의 Southwest Oncology Group(SWOG)이 제시 한 기준이 보편적으로 사용되며, 골수에서 비정상적인 형질세 포가 $10 \%$ 이상이거나 또는 조직학적으로 진단된 형질세포종, 소변이나 혈청에서의 $\mathrm{M}$ 단백의 검출, 그리고 용해성 골병변이 나 병적골절 등의 기준이 있다. 본 증례의 경우 골수 내 비정 상 형질세포가 $10 \%$ 이상이었으며, 용해성 골병변 역시 동반되 어 있는 상태로 symptomatic 카테고리에 해당하며, 혈청 $\beta$ 2-microglobulin 농도에 의존한 SWOG staging상 stage II 로 진단되었다.

다발성 골수종의 임상 증상으로는 골격근의 통증, 고칼슘 혈증, 골절 등의 골을 부식시키는 특성으로 인해 나타나는 증상이 대부분이며, 골수가 종양 세포로 대치되면서 면역 저 하 및 빈혈, 출혈 등의 증상이 나타나기도 한다. 골수 외 침범 으로는 침범된 뼈 주변 연부조직의 종괴로 나타나는 경우가 있으며, 혈행성 전파를 통해 비장, 간, 신장, 림프절 등으로 침 범하기도 하며 ${ }^{10)}$ 이에 따라 간, 신기능 저하가 동반되기도 한 다. 드물지만 부비동을 침범하는 경우도 있으며, 특히 접형동 이나 두개내 침범을 하는 경우 시력 저하 또는 복시, 심하게는 실명에 이르는 안과적 증상을 동반하기도 한다.5) 본 증례에서 는 시력 저하와 일반적인 부비동염 증상 이외에 다발성 골수 종을 의심할 만한 골격근이나 전신적인 증상은 전혀 없어서 안과와 신경과를 들러 이비인후과로 의뢰되었고, 조직검사 전에는 악성 임파종을 먼저 의심하였고 이를 위해 조직검사 를 시행하였다.

단발성으로 존재하는 비강 및 부비동에 국한된 골수 외 형 질세포종의 경우 방사선 치료에 잘 반응하기 때문에 방사선 치 료를 일차적으로 사용할 수 있다. 수술적 제거는 병변이 국소 적으로 위치하여 완전 절제할 수 있는 경우, 특히 종양이 유 경성인 경우에 시도할 수 있다. 국한된 병변의 경우 방사선 치 료나 수술적 절제술의 단독 혹은 병행요법의 결과는 서로 통 계적인 차이가 보이지 않는 것으로 알려져 있다.) 그러나 다발 성 골수종은 전신적인 질환의 국소적 발현이므로 항암화학 치료가 기초가 되며 국소적인 통증의 감소나 합병증의 치료 를 위해 국소 병소 제거나 방사선 치료를 병행하게 된다. ${ }^{11)}$ 본 증례의 경우 접형동 종양에서 출혈이 심하고 시신경을 둘러
싸고 있어 완전 절제가 불가능할 것으로 판단되었고, 향후 골수검사 등 전신검사 후 방사선 치료 및 항암치료를 계획하 였기에 종물의 국소제거는 시도하지 않았다.

다발성 골수종에 대한 항함화학치료로는 alkylating 제제 등의 약제가 기초가 되며, mephalan과 prednisone의 복합투 여가 1960년대 말 이후 표준 요법으로 이용되어 왔다. 최근들 어 thalidomide와 dexamethasone의 병용치료가 기존의 화학 요법에 비해 효과가 앞선다는 보고들이 있으며 ${ }^{12)}$ 재발성 다발 성 골수종에서 bortezomib, cyclophosphamide, dexamethasone을 병행하는 요법을 통해 생존기간을 증가시켰다는 보 고도 있다. ${ }^{13)}$ 골수 외 침범을 보이는 다발성 골수종의 경우, 치 료방법 및 약제의 선택은 동일한 것으로 되어 있으나, 치료효 과가 떨어지고, 재발률이 높은 것으로 보고되고 있다. ${ }^{14)}$

기존 보고들이 대부분 비강과 부비동에 발생한 골수 외 형 질세포종에 대한 보고이며 ${ }^{15)}$ 다발성 골수종의 비강 및 부비 동 침범의 예는 거의 없으며 상악동으로 진행된 다발성 골수 종의 사례가 국내에 보고된 바 있으나, ${ }^{11)}$ 이 증례의 경우 기존 다발성 골수종 환자에서 치료 후 추적 관찰한 영상의학적 검 사를 통해 상악동에 재발된 것을 발견한 환자의 증례로 시력 저하를 주소로 내원하여 부비동에서 먼저 진단하고 골수검 사를 통해 다발성 골수종을 진단한 본 증례는 차별점이 있 다고 하겠으며, 특히 다발성 골수종이 다른 부비동이 아닌 접 형동을 침범하여 시력 저하를 일으킨 아주 드문 증례라고 할 수 있겠다.

본 증례에서 술 전 저자들은 영상학적 검사를 통해 좌측 접형동의 종괴와 시신경관을 침범을 확인하여, 악성 종양을 의심 하에 조직검사를 시행하였고, 향후 항암치료로 인한 면 역저하에서 문제가 될 수 있는 동반된 비용 및 부비동염의 제거를 위해 수술을 함께 시행하던 중 양측 비강 및 부비동 점막의 이상소견을 발견하여 추가적인 조직검사를 시행하여 병리검사상 양측 모두에서 다발성 골수종의 부비동, 비강 내 침범으로 확인된 경우였다. 이와 같이 편측 시력 소실을 주 소로 내원한 환자에서 접형동 종양에 대한 조직검사를 할 경 우 악성 임파종뿐만 아니라 다발성 골수종을 비롯한 형질세 포종의 가능성도 염두에 두어야 하며, 본 증례와 같이 반대 측 비강 및 부비동까지 다발성으로 침범할 수 있다는 점에 대해서도 고려해야 한다.

\section{REFERENCES}

1) Willis RA. Principles of pathology. 2nd ed. London: Butterworth; 1961. p.554.

2) Palacios E, Restrepo S, Rojas R. Extramedullary plasmacytoma in the nasal cavity. Ear Nose Throat J 2002;81(8):499-500.

3) Alexiou C, Kau RJ, Dietzfelbinger H, Kremer M, Spiess JC, Schratzenstaller B, et al. Extramedullary plasmacytoma: tumor 
occurrence and therapeutic concepts. Cancer 1999;85(11):2305-14.

4) Bachmeyer C, Levy V, Carteret M, Laccourreye O, Danel C, Le Tourneau A, et al. Sphenoid sinus localization of multiple myeloma revealing evolution from benign gammopathy. Head Neck 1997;19 (4):347-50

5) Hogan MC, Lee A, Solberg LA, Thomé SD. Unusual presentation of multiple myeloma with unilateral visual loss and numb chin syndrome in a young adult. Am J Hematol 2002;70(1):55-9.

6) Wax MK, Yun KJ, Omar RA. Extramedullary plasmacytomas of the head and neck. Otolaryngol Head Neck Surg 1993;109(5):877-85.

7) Yang SH, Kim TY, Kim BK. A statistical study of multiple myeloma in Korea. Korean J Hematol 1995;30:345-61.

8) Raab MS, Podar K, Breitkreutz I, Richardson PG, Anderson KC. Multiple myeloma. Lancet 2009;374(9686):324-39.

9) Korea Central Cancer Registry, National Cancer Center. Annual report of cancer statistics in Korea in 2012. Seoul: Ministry of Health and Welfare;2014.

10) Bladé J, de Larrea CF, Rosiñol L. Extramedullary involvement in multiple myeloma. Haematologica 2012;97(11):1618-9.

11) Yoo CS, Kim JM, Chang HS, Kang JW. A case of maxillary sinus involvement in multiple myeloma. Korean J Otolaryngol-Head Neck Surg 1998;41(3):409-13.

12) Palumbo A, Bertola A, Falco P, Rosato R, Cavallo F, Giaccone L, et al. Efficacy of low-dose thalidomide and dexamethasone as first salvage regimen in multiple myeloma. Hematol J 2004;5(4):318-24.

13) Fu W, Delasalle K, Wang J, Song S, Hou J, Alexanian R, et al. Bortezomib-cyclophosphamide-dexamethasone for relapsing multiple myeloma. Am J Clin Oncol 2012;35(6):562-5.

14) Qu X, Chen L, Qiu H, Lu H, Wu H, Qiu H, et al. Extramedullary manifestation in multiple myeloma bears high incidence of poor cytogenetic aberration and novel agents resistance. Biomed Res Int 2015;2015:787809.

15) Park HJ, Moon KR, Pae JH, Lee SS. A case of multiple extramedullary plasmacytoma arising from both nasal cavity and nasopharynx. Korean J Otorhinolaryngol-Head Neck Surg 2009;52(6):541-4. 